
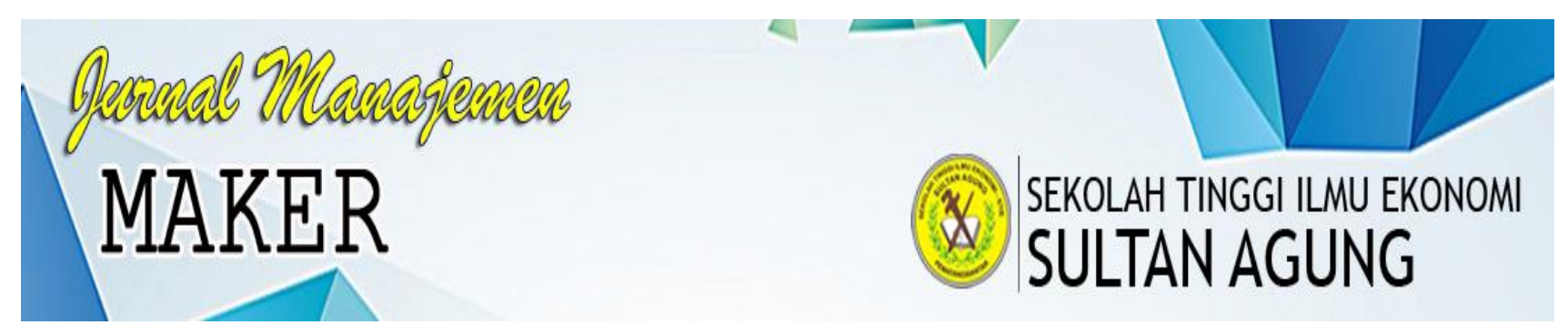

\title{
PENGARUH KOMITMEN PEGAWAI DAN DISIPLIN KERJA TERHADAP KINERJA PEGAWAI PADA DINAS KOPERASI, USAHA KECIL MENENGAH DAN PERDAGANGAN KOTA PEMATANGSIANTAR
}

\author{
Oleh: \\ Widya Mustika \\ Sarjana Manajemen \\ Darwin Lie, Efendi, Ady Inrawan
}

\begin{abstract}
Abstrak
Hasil penelitian ini dapat disimpulkan sebagai berikut: 1. Komitmen pegawai tinggi, disiplin kerja dan kinerja pegawai sudah baik. 2. Hasil regresi linier berganda menunjukkan adanya pengaruh positif antara komitmen pegawai dan disiplin kerja terhadap kinerja pegawai. 3. Hasil analisis korelasi terdapat hubungan yang kuat dan positif antara komitmen pegawai, disiplin kerja dengan kinerja pegawai pada Dinas Koperasi, Usaha Kecil Menengah dan Perdagangan Pematangsiantar. 4. Hasil uji hipotesis menyatakan H0 ditolak, artinya komitmen pegawai dan disiplin kerja berpengaruh positif dan signifikan terhadap kinerja pegawai pada Dinas Koperasi, Usaha Kecil Menengah dan Pedagangan Pematangsiantar baik secara simultan maupun parsial.
\end{abstract}

Kata Kunci: Komitmen Pegawai, Disiplin Kerja, dan Kinerja Pegawai

\section{Abstract}

The results of this study can summarized as follows: 1. Employee commitment is moderately high correlation, work discipline and employee performance are good. 2. The results of multiple linear regression indicate a positive influence between employee commitment and work discipline on employee performance. 3. The results of the analysis of the correlation coefficient have a moderately high and positive correlation between employee commitment, work discipline and employee performance at Dinas Koperasi, Usaha Kecil Menengah dan Perdagangan Pematangsiantar. 4. The hypothesis test results stated that HO was rejected, meaning that employee commitment and work discipline had a positive and significant effect on the performance of employees at Dinas Koperasi, Usaha Kecil Menengah dan Perdagangan Pematangsiantar both simultaneously and partially.

Keywords: Employee Commitment, Work Discipline, and Employee Performance

\section{A. PENDAHULUAN}

\section{Latar Belakang Masalah}

Sumber daya manusia mempunyai peranan penting dalam aktivitas organisasi, karena bagaimanapun juga kemajuan dan keberhasilan suatu organisasi tidak lepas dari peran dan kemampuan sumber daya manusia yang baik. Salah satu bagian penting yang berperan dalam menentukan keberhasilan perusahaan atau organisasi adalah dengan pembinaan tenaga kerja yang potensial. Perusahaan berusaha membina pegawai dengan semangat tinggi, menciptakan dan memelihara keunggulan sumber daya manusia yang mampu bersaing. Sumber daya manusia inilah yang pada akhirnya menjadi faktor utama bagi keberhasilan suatu perusahaan.

Dinas Koperasi, Usaha Kecil Menengah dan Perdagangan Kota Pematangsiantar yang bergerak pada pelayanan publik dalam hal pengawasan koperasi dan perdagangan. Sejumlah orang yang bekerja di dalam instansi tersebut saling bekerjasama dalam rangka mencapai tujuan tertentu yang dituangkan pada visi dan misi organisasi. Semua unsur dalam instansi ini harus dapat melibatkan diri dan 
memiliki dorongan yang kuat untuk mencapai apa yang menjadi tujuan dari Dinas Koperasi, Usaha Kecil Menengah dan Perdagangan Kota Pematangsiantar dengan memperhatikan faktor yang dapat medorong kinerja pegawainya.

Kinerja pegawai menjadi hal yang penting dan perlu diperhatikan dengan sangat serius oleh setiap instansi, karena kinerja pegawai dengan segala aspek yang ada didalamnya akan memberikan dampak secara keseluruhan pada kegiatan perusahaan. Kinerja pegawai pada Dinas Koperasi, Usaha Kecil Menengah dan Perdagangan Kota Pematangsiantar diukur dari dimensi berdasarkan Sasaran Kerja Pegawai (SKP) yang terdiri dari kuantitas, kualitas, waktu, dan biaya. Sedangkan pada Perilaku Kerja (PK) yang terdiri dari orientasi pelayanan, integritas, komitmen, disiplin, kerjasama, dan kepemimpinan. Berikut ini adalah fenomena kinerja pegawai pada Dinas Koperasi, Usaha Kecil Menengah dan Perdagangan Kota Pematangsiantar.

Tabel 1

Fenomena Kinerja Pegawai pada Dinas Koperasi, Usaha Kecil Menengah dan Perdagangan kota Pematangsiantar

\begin{tabular}{|c|c|c|c|c|c|c|}
\hline $\begin{array}{c}\text { Dimensi } \\
\text { Kinerja } \\
\text { Pegawai }\end{array}$ & $\begin{array}{c}\text { S } \\
\text { B }\end{array}$ & B & $\begin{array}{c}\text { C } \\
\text { B }\end{array}$ & $\begin{array}{c}\text { T } \\
\text { B }\end{array}$ & $\begin{array}{c}\text { ST } \\
\text { B }\end{array}$ & $\begin{array}{c}\text { Juml } \\
\text { ah }\end{array}$ \\
\hline Sasaran Kerja & $\begin{array}{c}15 \\
\%\end{array}$ & $\begin{array}{c}50 \\
\%\end{array}$ & $\begin{array}{c}35 \\
\%\end{array}$ & 0 & 0 & $100 \%$ \\
\hline Perilaku Kerja & $\begin{array}{c}15 \\
\%\end{array}$ & $\begin{array}{c}60 \\
\%\end{array}$ & $\begin{array}{c}25 \\
\%\end{array}$ & 0 & 0 & $100 \%$ \\
\hline $\begin{array}{c}\text { Nilai rata- } \\
\text { rata }\end{array}$ & $\begin{array}{c}\mathbf{1 5} \\
\mathbf{\%}\end{array}$ & $\begin{array}{c}\mathbf{5 5} \\
\mathbf{\%}\end{array}$ & $\begin{array}{c}\mathbf{3 0} \\
\text { \% }\end{array}$ & $\mathbf{0}$ & $\mathbf{0}$ & $\begin{array}{c}\mathbf{1 0 0} \\
\mathbf{\%}\end{array}$ \\
\hline
\end{tabular}

Sumber: Dinas Koperasi, Usaha Kecil Menengah dan Perdagangan Kota Pematangsiantar, Mei 2018.

Dari hasil wawancara pada Kassubag Umum Dinas Koperasi, Usaha Kecil Menengah dan Perdagangan kota Pematangsiantar, bahwa secara umum kinerja pegawai masih belum optimal. Hal ini dapat dilihat pada dimensi sasaran kerja pegawai terdapat 35\% kategori cukup baik. Hal ini menunjukkan bahwa masih adanya pegawai yang kurang memanfaatkan waktu bekerja secara optimal sehingga belum mampu mencapai target kerja dengan tepat waktu. Sedangkan pada dimensi perilaku kerja diperoleh persentase yaitu sebesar
$25 \%$ dengan kategori cukup baik. Hal ini menunjukkan bahwa masih terdapat pegawai yang kurang baik saat memberikan pelayanan kepada masyarakat, menundanunda dalam memberikan pelayanan serta tidak sigap dalam melayani masyarakat mengakibatkan pegawai belum mampu mencapai perilaku kerja yang telah diatur dalam peraturan pemerintah.

Faktor yang mempengaruhi kinerja pegawai adalah komitmen. Komitmen pegawai merupakan suatu sikap atau bentuk loyalitas yang ditunjukkan oleh seorang pegawai terhadap organisasi serta berniat memelihara keanggotaan dalam organisasi tersebut. Menurut Luthans (2006:236), sebagai suatu sikap, komitmen organisasi merupakan suatu hasrat atau motif yang kuat untuk tetap menjadi anggota organisasi, suatu keinginan untuk menunjukkan usaha tingkat tinggi atas nama organisasi, dan keyakinan yang kuat dalam menerima nilai-nilai organisasi, agar tercipta kinerja pegawai yang baik bagi perusahaan.

Fenomena komitmen yang ada pada Dinas Koperasi, Usaha Kecil Menengah dan Perdagangan kota Pematangsiantar masih belum optimal dilihat pada dimensi komitmen afektif dengan indikator mengorbankan kepentingan pribadi demi kemajuan instansi, hal ini terlihat dari masih adanya pegawai belum mampu dalam membagi tugas antara urusan kantor maupun dengan urusan pribadi seperti lebih mengedepankan menjemput anak sekolah dari pada melaksanakan tugas yang diberikan kepadanya. Pada dimensi komitmen berkelanjutan pegawai merasakan kepentingan untuk tetap bertahan di instansi. Pada dimensi komitmen normatif masih adanya beberapa pegawai yang kurang melibatkan dirinya pada setiap kegiatan dalam instansi.

Faktor lain yang dapat mempengaruhi kinerja pegawai adalah disiplin kerja. Disiplin kerja sangat menentukan sikap dan perilaku yang menjadi sebuah kebiasaan pegawai sehari-hari di dalam melakukan pekerjaan. Menurut Zainal, et. al. (2015:444), mengatakan bahwa disiplin pegawai yang tinggi, maka kinerja pegawai 
akan semakin tinggi pula dan sebaliknya jika disiplin pegawai menurun, maka kinerja pegawai akan semakin menurun. Dinas Koperasi, Usaha Kecil Menengah dan Perdagangan Kota Pematangsiantar menerapkan disiplin kerja berdasarkan Peraturan Pemerintah No. 53 Tahun 2010 dimana Pegawai Negeri Sipil memiliki kewajiban yang harus dijalankan dan larangan-larangan yang harus dijauhi agar terwujud disiplin kerja yang baik.

Fenomena disiplin pada Dinas Koperasi, Usaha Kecil Menengah dan Perdagangan kota Pematangsiantar masih belum optimal dilihat pada dimensi menjalankan kewajiban dengan indikator menaati ketentuan jam kerja, hal ini terlihat dari masih adanya pegawai yang tidak menaati ketentuan jam kerja seperti pegawai sering tidak masuk kerja, masuk dan keluar instansi tidak sesuai dengan peraturan dan sering terlambat masuk kantor. Pada dimensi menjauhi larangan menunjukkan masih adanya pegawai dengan sadar menerima hadiah yang berhubungan dengan jabatan untuk kepentingan pribadi.

\section{Rumusan Masalah}

a. Bagaimana gambaran komitmen pegawai, disiplin kerja dan kinerja pegawai pada Dinas Koperasi, Usaha Kecil Menengah dan Perdagangan kota Pematangsiantar.

b. Bagaimana pengaruh komitmen pegawai, dan disiplin kerja terhadap kinerja pegawai pada Dinas Koperasi, Usaha Kecil Menengah dan Perdagangan kota Pematangsiantar baik secara simultan maupun parsial.

\section{Tujuan Penelitian}

a. Untuk mengetahui gambaran karakteristik individu, lingkungan kerja dan kinerja pegawai pada Badan Pengelolaan Pajak dan Retribusi Daerah UPT SAMSAT Pematangsiantar.

b. Untuk mengetahui pengaruh karakteristik individu dan lingkungan kerja terhadap kinerja pegawai pada Badan Pengelolaan Pajak dan Retribusi Daerah UPT SAMSAT Pematangsiantar baik secara simultan maupun parsial.

\section{Metode Penelitian}

Tempat penelitian dilakukan pada Dinas Koperasi, Usaha Kecil Menengah dan Perdagangan Kota Pematangsiantar yang beralamat Jalan Cempaka Nomor 2, Kecamatan Siantar Barat, Kelurahan Simarito, No. Telepon (0622) 23766, Email: disperindagps@gmail.com, Kode Pos 21113. Populasi penelitian seluruh Pegawai Negeri Sipil (PNS) pada Dinas Koperasi, Usaha Kecil Menengah dan Perdagangan Kota Pematangsiantar yang berjumlah 71 orang pegawai dan seluruhnya dijadikan sebagai sampel.

Desain penelitian adalah Penelitian Kepustakaan (Library Reseacrh) dan Penelitian lapangan (Field Research).Teknik pengumpulan data berupa Kuesioner, Wawancara, dan Dokumentasi.Jenis data yang digunakan dalam penelitian ini yaitu data kualitatif dan kuantitatif. Hasil data yang diperoleh dari lapangan akan dianalisis secara deskriptif baik bersifat kualitatif dan kuantitatif.

\section{B. LANDASAN TEORI}

\section{Manajemen}

Manajemen Untuk mencapai tujuan organisasi yang baik, perusahaan atau organisasi harus memiliki manajemen yang baik pula. Manajemen dikatakan baik apabila mampu mengatur orang-orang di dalam perusahaan untuk dapat bekerja secara lebih baik sehingga tujuan perusahaan dapat tercapai.

Menurut Zainal, et. al. (2015:4), "manajemen diartikan sebagai kumpulan pengetahuan tentang bagaimana seharusnya memanage (mengelola) sumber daya manusia”. Menurut Daft (2002:8), "manajemen yaitu pencapaian sasaransasaran organisasi dengan cara yang efektif dan efisien melalui perencanaan, pengorganisasian, kepemimpinan dan pengendalian sumber daya organisasi".

Menurut Griffin (2004:8), "manajemen merupakan suatu rangkaian aktifitas (termasuk perencanaan, dan pengambilan keputusan, pengorganisasian, kepemimpinan dan pengendalian) yang diarahkan pada sumber-sumber daya organisasi (manusia, financial, fisik dan 
informasi untuk mencapai tujuan organisasi dengan cara efektif dan efisien".

Berdasarkan pendapat para ahli di atas, maka penulis meyimpulkan bahwa manajemen adalah suatu proses atau tindakan perencanaan, pengorganisasian, penggerakan, dan pengendalian sumber daya manusia sehingga dapat mencapai tujuan organisasi yang efektif dan efisien.

\section{Manajemen Sumber Daya Manusia}

Dalam suatu organisasi, manajemen sumber daya manusia memiliki peran penting dalam mencapai tujuannya. Tanpa adanya sumber daya manusia operasional suatu organisasi tidak dapat berjalan dengan lancar. Menurut Mangkunegara (2017:2), "manajemen sumber daya manusia yaitu suatu perencanaan, pengorganisasian, pengkoordinasian, pelaksanaan dan pengawasan terhadap pengadaan, pengembangan, pemberian balas jasa, pengintegrasian, pemeliharaan dan pemisahan tenaga kerja dalam mencapai tujuan organisasi". Menurut Bangun (2012:6), "manajemen sumber daya manusia yaitu proses perencanaan, pengorganisasian, penyusunan staf, penggerakan, dan pengawasan terhadap pengadaan, pengembangan, pemberian kompensasi, pengintegrasian dan pemisahan tenaga kerja untuk mencapai tujuan suatu organisasi”.

Menurut Sutrisno

(2011:7),

"manajemen sumber daya manusia sebagai suatu perencanaan, pengorganisasian, pengarahan dan pengawasan atas pengadaan, pengembangan, kompensasi, pengintegrasian, pemeliharaan dan pemutusan hubungan kerja dengan maksud untuk mencapai tujuan organisasi perusahaan". Berdasarkan pendapat para ahli tersebut, maka penulis mengambil kesimpulan bahwa manajemen sumber daya manusia adalah suatu sumber daya dimana manusia yang merancang sistem-sistem formal berupa proses perencanaan, pengorganisasian, pengarahan, penyusunan staf, pemberian kompensasi, pengintegrasian, pemeliharaan dan pemutusan hubungan kerja dengan maksud untuk mencapai tujuan organisasi.

\section{Komitmen Pegawai}

Dalam setiap perusahaan tetap membutuhkan pegawai sebagai bagian dari perusahaan. Namun dalam menjadi bagian dari perusahaan, maka pegawai perlu dilatih untuk memiliki komitmen. Komitmen menjadi peranan penting dalam perusahaan, pegawai yang memiliki komitmen menjadi faktor penunjang dalam menjalankan komitmen organisasi.

Menurut Sutrisno (2011:296), "komitmen organisasi merupakan sikap loyalitas pekerja terhadap organisasinya dan juga merupakan suatu proses mengekspresikan perhatian dan partisipasinya terhadap organisasi”. Menurut Panggabean (2004:135), "komitmen organisasi adalah kuatnya pengenalan dan keterlibatan seseorang dalam suatu organisasi tertentu". Menurut Robbins dan Mary (2010:40), "komitmen organisasi merupakan derajat di mana seorang karyawan mengidentifikasikan dirinya dengan organisasi tertentu beserta tujuannya dan berkeinginan untuk mempertahankan keanggotaannya di dalam organisasi tersebut".

Sedangkan menurut Luthans (2006:249), komitmen organisasi paling sering didefinisikan sebagai:

a. Keinginan kuat untuk tetap menjadi anggota organisasi tertentu.

b. Keinginan untuk berusaha keras sesuai keinginan organisasi.

c. Keyakinan dan penerimaan nilai dan tujuan organisasi.

Berdasarkan definisi para ahli tersebut, maka dapat disimpulkan bahwa komitmen adalah sikap loyalitas pegawai dalam bekerja serta merupakan suatu proses mengekspresikan keinginan dan keyakinan berdasarkan kesepakatan serta partisipasi yang ditujukan kepada organisasi yang telah ditentukan.

\section{Disiplin Kerja}

Disiplin kerja yang diterapkan dan dilakukan terhadap karyawan adalah untuk dapat menciptakan sebuah suasana kerja yang baik dimana dapat menghasilkan sebuah tingkat produktivitas yang baik dalam rangka pengembangan tujuan dan target perusahaan. Disiplin kerja dapat 
tercermin dalam pemenuhan tugas dan tanggung jawab kerja, gairah, dan minat terhadap pekerjaan maupun keikutsertaan seorang karyawan dalam mewujudkan perusahaan atau organisasi. Menurut Zainal et, al (2015:599), "disiplin kerja adalah suatu alat yang digunakan para manajer untuk berkomunikasi dengan karyawan agar mereka bersedia untuk mengubah suatu perilaku serta sebagai suatu upaya untuk meningkatkan kesediaan seseorang dalam mentaati semua peraturan perusahaan dan norma-norma sosial yang berlaku".

Berdasarkan Peraturan Pemerintah Republik Indonesia No. 53 Tahun 2010 Tentang Disiplin Kerja Pegawai Negeri Sipil, ”Disiplin Pegawai Negeri Sipil adalah kesanggupan Pegawai Negeri Sipil untuk menaat semua kewajiban dan menghindari larangan yang ditentukan dalam peraturan perundang-undangan dan/ atau peraturan kedinasan yang apabila tidak ditaati atau dilanggar dijatuhi hukuman disiplin." Menurut Mulyadi (2016:48), "disiplin kerja adalah sikap kesediaan dan kerelaan seseorang untuk mematuhi dan menaati norma-norma peraturan yang berlaku disekitarnya". Berdasarkan pendapat para ahli tersebut, maka penulis menyimpulkan bahwa disiplin kerja adalah suatu perilaku serta upaya seseorang untuk mentaati peraturan perusahaan yang sebenarnya dan yang telah ditetapkan dan mematuhi normanorma sosial yang berlaku serta menaati kewajiban dan menjauhi larangan.

\section{Kinerja Pegawai}

Kinerja pegawai merupakan hasil kerja yang telah dilaksanakan oleh pegawai untuk mencapai tujuan organisasi, jika kinerja pegawai tidak optimal maka tujuan suatu organisasi tidak tercapai. Menurut Sutrisno (2011:170), "mengemukakan kinerja adalah kesuksesan seseorang dalam melaksanakan tugas". Menurut Zainal, et. al (2015:406), "Kinerja dapat diartikan sebagai suatu fungsi dari motivasi dan kemampuan”. Sedangkan menurut Mathis dan John (2006:113), "kinerja adalah suatu hasil kerja yang dicapai seseorang dalam melaksanakan tugas-tugas yang dibebankan kepadanya yang disarankan atas pengalaman, kesungguhan dan kecakapan serta waktu".

Berdasarkan pendapat para ahli tersebut, maka penulis menyimpulkan bahwa kinerja merupakan hasil kerja yang ditunjukkan oleh individu yang memperlihatkan seberapa jauh kemampuan seorang individu dalam organisasi atau perusahaan serta kesungguhan dan pengalaman individu tersebut.

\section{PEMBAHASAN}

\section{Analisis}

\section{a. Deskriptif Kualitatif}

Analisis deskriptif Analisis deskriptif kualitatif dimaksudkan untuk mendapatkan gambaran atau deskripsi mengenai tanggapan dari pegawai mengenai pengaruh komitmen pegawai dan disiplin kerja terhadap kinerja pegawai pada Dinas Koperasi, Usaha Kecil Menengah dan Perdagangan Kota Pematangsiantar. Sesudah pengujian data maka langkah selanjutnya peneliti melakukan pengkajian analisis kualitatif sebagai gambaran fenomena dari variabel penelitian pada saat sekarang ini.

Adapun penetapan kriteria nilai ratarata jawaban dari responden tersebut dimasukkan kedalam kelas-kelas interval dimana penentuan intervalnya memakai rumus sebagai berikut:

Tabel 2

Nilai Interval dan Kategori Jawaban Responden

\begin{tabular}{|c|c|c|c|}
\hline \multirow{2}{*}{$\begin{array}{c}\text { Nilai } \\
\text { Inter } \\
\text { val } \\
\end{array}$} & \multicolumn{3}{|c|}{ Kategori } \\
\hline & $\begin{array}{l}\text { Komitme } \\
\text { n Pegawai }\end{array}$ & $\begin{array}{c}\text { Disiplin } \\
\text { Kerja }\end{array}$ & $\begin{array}{l}\text { Kinerja } \\
\text { Pegawai }\end{array}$ \\
\hline $\begin{array}{c}1,00- \\
1,80\end{array}$ & $\begin{array}{l}\text { Sangat } \\
\text { Rendah }\end{array}$ & $\begin{array}{c}\text { Sangat } \\
\text { Tidak } \\
\text { Baik } \\
\end{array}$ & $\begin{array}{c}\text { Sangat Tidak } \\
\text { Baik }\end{array}$ \\
\hline $\begin{array}{c}1,81- \\
2,60\end{array}$ & Rendah & $\begin{array}{l}\text { Tidak } \\
\text { Baik }\end{array}$ & Tidak Baik \\
\hline $\begin{array}{c}2,61- \\
3,40\end{array}$ & Sedang & $\begin{array}{c}\text { Cukup } \\
\text { Baik }\end{array}$ & $\begin{array}{c}\text { Cukup } \\
\text { Baik }\end{array}$ \\
\hline $\begin{array}{c}3,41- \\
4,20\end{array}$ & Tinggi & Baik & Baik \\
\hline $\begin{array}{c}4,21- \\
5.00\end{array}$ & $\begin{array}{l}\text { Sangat } \\
\text { Tinggi }\end{array}$ & $\begin{array}{c}\text { Sangat } \\
\text { Baik }\end{array}$ & Sangat Baik \\
\hline
\end{tabular}

Sumber: hasil pengolahan data (2018)

1) Gambaran Komitmen Pegawai Pada Dinas Koperasi, Usaha Kecil Menengah dan Perdagangan Kota Pematangsiantar

Pada dimensi komitmen afektif pada indikator kebahagiaan melaksanakan tugas 
diperoleh nilai rata-rata 3,59 dengan kriteria jawaban tinggi, hal ini dikarenakan tugas yang diberikan sesuai dengan kemampuan pegawai dan menganggap bahwa bekerja merupakan sebagian dari ibadah. Pada Indikator kebanggaan menjadi bagian organisasi, diperoleh nilai rata-rata 3,77 dengan kriteria jawaban tinggi, hal ini dikarenakan pegawai dapat membantu masyarakat dalam membuka usaha kecil sehingga pegawai bangga menjadi bagian dari organisasi. Pada Indikator merasa menjadi bagian dari keluarga pada organisasi, diperoleh nilai rata-rata 3,65 dengan kriteria jawaban tinggi, hal ini dikarenakan sesama rekan kerja di instansi memiliki kepedulian terhadap pegawai yang satu dengan yang lain.

Pada indikator terakhir kesediaan pegawai untuk mengorbankan kepentingan pribadi demi kemajuan instansi diperoleh nilai rata-rata 3,37 dengan kriteria jawaban cukup tinggi, hal ini dikarenakan pegawai belum mampu dalam membagi tugas antara urusan kantor maupun dengan urusan pribadi seperti lebih mengedepankan menjemput anak sekolah dari pada melaksanakan tugas yang diberikan kepadanya.

Selanjutnya untuk dimensi komitmen berkelanjutan, pada indikator menganggap pekerjaannya sebagai kesempatan yang baik memperoleh nilai rata-rata 3,63 dengan kriteria jawaban tinggi, dikarenakan pegawai merasa bahwa bekerja di instansi merupakan kesempatan terbaik untuk mengembangkan karir sesuai dengan kemampuan pegawai. Pada indikator keuntungan yang diberikan organisasi, diperoleh nilai rata-rata 4,06 dengan kriteria jawaban tinggi, dikarenakan instansi memberikan apa yang dibutuhkan oleh pegawai dalam memajukan kinerja pegawai. Pada Indikator kepentingan yang dirasakan untuk tetap bertahan diperoleh nilai rata-rata 3,54 dengan kriteria jawaban tinggi, dikarenakan pegawai menganggap bahwa bekerja di instansi merupakan suatu kebutuhan dan kewajiban. Selanjutnya pada indikator merasa khawatir jika meninggalkan instansi diperoleh nilai ratarata 3,76 dengan kriteria jawaban tinggi, hal ini dikarenakan pegawai sudah merasa nyaman berada pada lingkungan instansi serta rekan kerja mereka.

Dimensi yang terakhir komitmen normatif, pada indikator loyalitas pegawai terhadap instansi diperoleh nilai rata-rata 3,63 dengan kriteria jawaban tinggi, dikarenakan pegawai memiliki komitmen untuk setia dan tetap berada pada instansi. Pada indikator keterlibatan dalam organisasi diperoleh nilai rata-rata 4,00 dengan kriteria jawaban tinggi, hal ini dikarenakan setiap ada kegiatan dalam instansi pegawai selalu ikut serta dalam kegiatan tersebut. Pada indikator keinginan untuk melanjutkan sisa karir diperoleh nilai rata-rata 4,11 dengan kriteria jawaban tinggi, hal ini dikarenakan pegawai sudah memiliki keterikatan terhadap instansi sehingga pegawai memiliki keinginan untuk melanjutkan sisa karirnya. Pada indikator terakhir kewajiban untuk tetap bekerja pada instansi diperoleh nilai rata-rata 3,54 dengan kriteria jawaban tinggi, hal ini dikarenakan adanya kesadaran dan keterikatan pegawai akan tugas dan tanggung jawab terhadap instansi.

Dari total jawaban responden mengenai komitmen afektif, komitmen berkelanjutan dan komitmen normatif mendapat nilai rata-rata sebesar 3,72 dengan kriteria jawaban tinggi. Kemudian nilai rata-rata tertinggi 4,11 dengan kriteria jawaban tinggi untuk dimensi komitmen normatif pada indikator keinginan untuk melanjutkan sisa karir. Sedangkan nilai rata-rata terendah sebesar 3,37 dengan kriteria jawaban cukup tinggi untuk dimensi komitmen afektif pada indikator kesediaan mengorbankan kepentingan pribadi demi kemajuan instansi.

2) Gambaran Disiplin Kerja Pada
Dinas Koperasi, Usaha Kecil
Menengah dan Perdagangan Kota
Pematangsiantar
Untuk dimensi menjalankan kewajiban pada indikator mengucapkan sumpah PNS diperoleh nilai rata-rata 3,58 dengan kriteria jawaban baik, dikarenakan pegawai dengan baik dan bersungguhsungguh dalam mengucapkan sumpah PNS. Indikator mengucapkan sumpah jabatan diperoleh nilai rata-rata 3,76 dengan kriteria 
jawaban baik, dikarenakan adanya kesadaran pegawai bahwa sumpah jabatan dapat membuat pegawai tidak memanfaatkan jabatannya untuk hal-hal negatif.

Pada indikator setia terhadap pancasila diperoleh nilai rata-rata 3,77 dengan kriteria jawaban baik, dikarenakan pegawai tetap menerapkan nilai-nilai yang ada dalam Pancasila dalam keidupan dan pekerjaannya. Pada indikator setia terhadap Negara diperoleh nilai rata-rata 3,58 dengan kriteria jawaban baik, dikarenakan pegawai ikut berpartisipasi dalam setiap acara yang bersangkutan dengan Negara, dan pegawai bersemangat dalam menyelesaikan tugas yang diberikan Negara. Pada indikator menaati peraturan perundang-undangan diperoleh nilai rata-rata 3,76 dengan kriteria jawaban baik, dikarenakan pegawai memahami aturan-aturan yang mengatur setiap tindakan pegawai dalam bernegara.

Indikator melaksanakan tugas kedinasan diperoleh nilai rata-rata 3,77 dengan kriteria jawaban baik, dikarenakan adanya keinginan pegawai untuk mencapai tujuan organisasi serta tujuan karir yang diinginkan pegawai. Pada indikator menjaga kehormatan Negara diperoleh nilai rata-rata 3,58 dengan kriteria jawaban baik, disebabkan adanya kesadaran pegawai untuk menjaga nama baik dirinya sebagai seorang PNS dan nama baik Negaranya. Indikator mengutamakan kepentingan Negara diperoleh nilai rata-rata 3,76 dengan kriteria jawaban baik, dikarenakan adanya kemauan pegawai untuk tetap mengutamakan kepentingan yang menyangkut Negara.

Indikator memegang rahasia jabatan jawaban diperoleh nilai rata-rata 3,77 dengan kriteria jawaban baik, hal ini dikarenakan setiap pegawai telah mengucapkan sumpah jabatannya untuk dapat dipercaya dan memegang rahasia jabatannya. Pada indikator bekerja dengan jujur diperoleh nilai rata-rata 3,86 dengan kriteria jawaban baik, hal ini dikarenakan pegawai memiliki kemauan untuk bekerja dengan jujur dan tidak ada yang ditutupi dalam melakukan hal apapun. Indikator melaporkan apabila ada hal yang membahayakan Negara diperoleh nilai ratarata 3,77 dengan kriteria jawaban baik, dikarenakan pegawai sadar akan tanggung jawabnya kepada Negara karena baginya hal yang membahayakan Negara juga akan berbahaya bagi masa depan bangsa.

Indikator menaati ketentuan jam kerja diperoleh nilai rata-rata 3,23 dengan kriiteria jawaban cukup baik, dikarenakan kurangnya kesadaran pegawai dalam menaati ketentuan jam kerja seperti pegawai sering tidak masuk kerja, masuk dan keluar instansi tidak sesuai dengan peraturan dan sering terlambat masuk kantor. Indikator mencapai sasaran kerja pegawai diperoleh nilai rata-rata 3,68 dengan kriteria jawaban baik, hal ini dikarenakan pegawai dapat mencapai sasaran kerja karena adanya rencana kerja dan target yang akan dicapai oleh setiap pegawai. Indikator memelihara barang-barang milik Negara diperoleh nilai rata-rata 3,58 dengan kriteria jawaban baik, dikarenakan adanya kesadaran pegawai untuk menjaga dan memanfaatkan barang pemberian Negara dengan baik.

Indikator memberikan pelayanan yang baik untuk masyarakat diperoleh nilai ratarata 3,76 dengan kriteria jawaban baik, dikarenakan pegawai menyadari tanggung jawabnya di instansi tersebut adalah melayani kebutuhan masyarakat seperti melayani masyarakat yang mengajukan izin untuk membuka usaha kecil. Indikator membimbing bawahan dalam melaksanakan tugas diperoleh nilai rata-rata 3,77 dengan kriteria jawaban baik, dikarenakan sudah terjalinnya hubungan yang baik antara pegawai senior dengan pegawai junior. Indikator memberikan kesempatan bawahan untuk mengembangkan karir diperoleh nilai rata-rata 3,80 dengan kriteria jawaban baik, hal ini dikarenakan atasan memberikan arahan kepada setiap bawahan untuk mengembangkan karir dengan memberikan pelatihan.

Dimensi menjauhi larangan untuk indikator menyalahgunakan wewenang yang diberikan diperoleh nilai rata-rata 3,76 dengan kriteria jawaban baik, dikarenakan pegawai menyadari bahwa menyalahgunakan wewenang yang diberikan merupakan bentuk larangan bagi 
setiap PNS dan dapat merugikan dirinya sendiri. Indikator untuk tidak menjadi perantara untuk mendapatkan keuntungan pribadi diperoleh nilai rata-rata 3,80 dengan kriteria jawaban baik, hal ini disebabkan pegawai tidak menggunakan kewenangan orang lain demi mendapatkan keuntungan pribadi. Indikator tanpa izin pemerintah bekerja pada Negara lain diperoleh nilai rata-rata 3,54 dengan kriteria jawaban baik, dikarenakan adanya kesadaran pegawai untuk tetap setia terhadap pekerjaan yang telah dijalaninya.

Indikator tidak bekerja pada perusahaan asing diperoleh nilai rata-rata 3,58 dengan kriteria jawaban baik, dikarenakan tidak adanya pegawai yang bekerja pada Negara asing karena pemerintah memberikan gaji kepada setiap PNS berdasarkan tingkat golongan pegawai dan menjamin kehidupan PNS. Indikator untuk tidak memiliki barang-barang milik Negara secara tidak sah diperoleh nilai ratarata 3,76 dengan kriteria jawaban baik, dikarenakan pegawai mengetahui bahwa barang-barang milik Negara hanya dipergunakan untuk kepentingan pekerjaan bukan untuk kepentingan pribadi. Pada indikator tidak melakukan kegiatan bersama untuk kepentingan pribadi diperoleh nilai rat-rata 3,73, dikarenakan atasan selalu tegas kepada pegawai untuk tidak melakukan kegiatan bersama, di dalam maupun di luar lingkungan kerja dengan tujuan mencari keuntungan pribadi.

Indikator tidak memberikan hadiah pada seseorang untuk diangkat dalam jabatan diperoleh nilai rata-rata 4,07 dengan kriteria baik, hal ini dikarenakan pegawai tidak pernah memberi hadiah kepada siapapun baik secara langsung maupun tidak langsung dengan dalih apapun untuk diangkat dalam jabatan. Pada indikator tidak menerima hadiah yang berhubungan dengan jabatan diperoleh nilai rata-rata 3,56 dengan kriteria jawaban baik, hal ini dikarenakan hal tersebut dapat menciptakan tindakan korupsi yang merusak citra instansi dan dirinya sebagai seorang PNS. Indikator tidak bertindak sewenang-wenang terhadap bawahan diperoleh nilai rata-rata 3,75 dengan kriteria jawaban baik, dikarenakan hubungan dan komunikasi yang baik telah terjalin antara atasan dan bawahan.

Indikator pelayanan kepada masyarakat diperoleh nilai rata-rata 3,75 dengan kriteria jawaban baik, dikarenakan pegawai memberikan pelayanan yang baik kepada masyarakat. Indikator tidak menghalangi berjalannya tugas kedinasan diperoleh nilai rata-rata 3,76 dengan kriteria jawaban baik, dikarenakan tidak adanya pegawai yang menghalangi berjalannya tugas kedinasan yang akan merugikan organisasi. Pada indikator tidak menjadi peserta kampanye dengan menggunakan atribut PNS diperoleh nilai rata-rata 3,58 dengan kriteria jawaban baik, dikarenakan adanya kesadaran pegawai untuk bersikap netral dalam pemilihan umum.

Indikator tidak mendukung calon peserta pemilu menggunakan fasilitas Negara diperoleh nilai rata-rata 3,73 dengan kriteria jawaban baik, dikarenakan adanya kesadaran pegawai untuk menggunakan fasilitas yang diberikan Negara hanya ketika pegawai menjalankan tugas kedinasan yang telah dipercayakan padanya. Kemudian pada indikator terakhir tidak membuat keputusan yang menguntungkan salah satu calon peserta pemilu diperoleh nilai ratarata 3,75 dengan kriteria jawaban baik, hal ini dikarenakan adanya kesadaran pegawai untuk membuat keputusan yang seadiladilnya dan tidak merugikan pihak manapun. Indikator mengadakan kegiatan yang mengarah kepada keberpihakan terhadap pasangan calon pemilu diperoleh nilai rata-rata 3,73 dengan kriteria jawaban baik, hal ini dikarenakan pegawai adil dalam memilih pasangan calon pemilu.

Dari total jawaban responden mengenai disiplin kerja berdasarkan menjalankan kewajiban dan menjauhi larangan mendapat nilai rata-rata sebesar 3,71 dengan kriteria jawaban baik. Kemudian nilai rata-rata tertinggi 4,07 dengan kriteria jawaban baik untuk dimensi menjauhi larangan pada indikator memberikan hadiah pada seseorang untuk diangkat dalam jabatan. Sedangkan nilai rata-rata terendah sebesar 3,23 dengan kriteria jawaban cukup baik untuk dimensi 
menjalankan kewajiban dengan indikator menaati ketentuan jam kerja.

\section{3) Gambaran Kinerja Pegawai pada \\ Dinas Koperasi, Usaha Kecil \\ Menengah dan Perdagangan Kota \\ Pematangsiantar}

Dimensi sasaran kerja pegawai untuk indikator kuantitas ketekunan diperoleh nilai rata-rata 3,59 dengan kriteria jawaban baik, dikarenakan pegawai dengan penuh ketekunan dalam menyelesaikan pekerjaan yang diterimanya. Pada indikator kuantitas pencapaian target memperoleh nilai ratarata 3,75 dengan kriteria jawaban baik, hal ini dikarenakan pegawai selalu berusaha mencapai target kerja. Indikator kualitas tingkat ketelitian diperoleh nilai rata-rata 3,68 dengan kriteria jawaban baik, hal ini dikarenakan pegawai selalu berhati-hati dalam melakukan pekerjaannya agar tidak menimbulkan permasalahan bagi instansii.

Pada indikator kualitas tingkat mutu hasil kerja memperoleh nilai rata-rata 3,61 dengan kriteria jawaban baik, hal ini dikarenakan setiap pekerjaan yang dikerjakan oleh pegawai dilakukan dengan sungguh-sungguh. Indikator ketepatan waktu diperoleh nilai rata-rata 3,18 dengan kriteria jawaban cukup baik, hal ini dikarenakan masih adanya pegawai yang kurang memanfaatkan waktu bekerja secara optimal sehingga tidak dapat menyelesaikan pekerjaan dengan tepat waktu. Indikator ketepatan waktu kehadiran diperoleh nilai rata-rata 3,66 dengan kriteria jawaban baik, dikarenakan pegawai menyadari bahwa kehadiran dapat meningkatkan produktivitas pekerjaannya..

Pada indikator anggaran yang dibutuhkan pegawai diperoleh nilai rata-rata 3,59 dengan kriteria jawaban baik, hal ini dikarenakan jumlah anggaran yang diberikan kepada pegawai sesuai dengan yang dibutuhkan. Indikator kemampuan mengalokasikan biaya diperoleh nilai ratarata 3,72 dengan kriteria jawaban baik, dikarenakan pegawai mampu mengalokasikan biaya yang diberikan dengan baik.

Untuk dimensi perilaku kerja dengan indikator tingkat pelayanan diperoleh nilai rata-rata 3,31 dengan kriteria jawaban cukup baik, hal ini dikarenakan sebagai pegawai negeri sipil sebaiknya pegawai memberikan pelayanan sebaik-baiknya kepada masyarakat dan tidak menundanunda dalam memberikan pelayanan serta selalu tanggap dalam melayani masyarakat yang telah diatur dalam peraturan pemerintah. Pada indikator sikap dan perilaku saat memberikan pelayanan diperoleh nilai rata-rata 3,72 dengan kriteria jawaban baik, hal ini dikarenakan pegawai bersikap baik saat memberikan pelayanan kepada masyarakat. Indikator etika pegawai diperoleh nilai rata-rata 3,54 dengan kriteria jawaban baik, dikarenakan di dalam instansi pegawai menaati peraturan sesuai prosedur instansi.

Indikator kemampuan dalam bertindak diperoleh nilai rata-rata 3,75 dengan kriteria jawaban baik, dikarenakan pegawai memiliki kemampuan yang baik dalam bekerja. Pada indikator komitmen pegawai diperoleh nilai rata-rata 3,51 dengan kriteria jawaban baik, hal ini dikarenakan pegawai memiliki komitmen dan loyalitas terhadap instansi. Selanjutnya pada indikator kesediaan melakukan pekerjaan tanpa diperintah atasan diperoleh nilai rata-rata 3,72 dengan kriteria jawaban baik, hal ini dikarenakan pegawai memiliki kemauan dan inisiatif dalam melaksanakan tugas tanpa diperintah oleh atasan atau pimpinan.

Pada indikator kewajiban melaksanakan tugas diperoleh nilai rata-rata 3,48 dengan kriteria jawaban baik, dikarenakan kewajiban pegawai yaitu mengerjakan setiap pekerjaan dan tanggung jawabnya terhadap organisasi. Pada indikator pemberian sanksi diperoleh nilai rata-rata 3,72 dnegan kriteria baik, hal ini dikarenakan pimpinan adil dalam meberikan sanksi kepada setiap pegawai yang melanggar aturan sesuai dengan peraturan pemerintah. Selanjutnya pada indikator kerja sama antar pegawai diperoleh nilai rata-rata 3,75 dengan kriteria jawaban baik, dikarenakan hubungan diantara sesama pegawai sudah terjalin baik. Pada indikator hubungan dengan atasan diperoleh nilai rata-rata 3,59 dengan kriteria jawaban baik, hal ini dikarenakan 
pegawai memiliki hubungan yang baik dengan atasan, dan atasan mau memberikan saran kepada pegawai.

Indikator pimpinan mempengaruhi pegawai diperoleh nilai rata-rata 3,54 dengan kriteria jawaban baik, hal ini dikarenakan pimpinan memiliki kemampuan mempengaruhi, seperti memberikan motivasi atau dorongan kepada pegawai untuk mencapai tujuan organisasi. Pada indikator terakhir menempatkan posisi pegawai diperoleh nilai rata-rata 3,75 dengan kriteria jawaban baik, hal ini dikarenakan pimpinan bijaksana dalam menempatkan setiap pegawai sesuai dengan keahliannya masing-masing.

Dari total jawaban responden mengenai dimensi sasaran kerja pegawai dan perilaku kerja mendapat nilai rata-rata sebesar 3,52 dengan kriteria jawaban baik. Kemudian nilai rata-rata tertinggi 3,75 dengan kriteria jawaban baik untuk dimensi sasaran kerja pegawai pada indikator kuantitas pencapaian target, untuk dimensi perilaku pegawai dengan indikator kemampuan dalam bertindak, kerja kelompok bersama rekan kerja, dan kepemimpinan yang bijaksana dalam instansi. Sedangkan nilai rata-rata terendah sebesar 3,18 dengan kriteria jawaban cukup baik untuk dimensi perilaku kerja pada indikator tingkat pelayanan.

\section{b. Deskriptif Kuantitatif}

\section{1) Analisa Regresi Linear Berganda}

Penelitian ini memiliki tujuan untuk menganalisis pengaruh komitmen pegawai dan disiplin kerja terhadap kinerja pegawai pada Dinas Koperasi, Usaha Kecil Menengah dan Perdagangan kota Pematangsiantar. Analisis data yang digunakan dalam analisis regresi linier berganda. Analisis regresi linier berganda digunakan untuk mengetahui pengaruh variabel bebas $(\mathrm{X})$ dan variabel terikat $(\mathrm{Y})$, dimana $X$ adalah komitmen pegawai, disiplin kerja dan Y adalah kinerja pegawai.

Analisis dijalankan dengan menggunakan tabulasi jawaban responden pada kuesioner yang telah dijalankan.
Tabel 3

Hasil Regresi Linier Berganda

\begin{tabular}{|c|c|c|c|}
\hline \multirow{2}{*}{ Model } & \multicolumn{2}{|c|}{$\begin{array}{l}\text { Unstandardize } \\
\text { d Coefficients }\end{array}$} & $\begin{array}{c}\text { Standardized } \\
\text { Coefficients }\end{array}$ \\
\hline & $\boldsymbol{B}$ & $\begin{array}{c}\text { Std. } \\
\text { Error }\end{array}$ & Beta \\
\hline (Constant) & 15.756 & 7.099 & \\
\hline $1 \begin{array}{l}\text { Komitmen } \\
\text { Pegawai } \\
\text { (X1) }\end{array}$ & .833 & .205 & .496 \\
\hline $\begin{array}{l}\text { Disiplin } \\
\text { Kerja (X2) }\end{array}$ & .162 & .077 & .255 \\
\hline
\end{tabular}

a. Dependent Variable: kinerja pegawai (Y) Sumber: hasil pengolahan kuesioner menggunakan SPSS versi 21 (2018)

Berdasarkan hasil pengolahan data pada tabel 3 di atas, diperoleh model persamaan $\hat{\mathrm{Y}}=15,756+0,833 \mathrm{X}_{1}+$ $0,162 \mathrm{X}_{2}$, artinya terdapat pengaruh positif antara Komitmen pegawai dan Disiplin Kerja terhadap Kinerja Pegawai pada Dinas Koperasi, Usaha Kecil Menengah dan Perdagangan kota Pematangsiantar.

\section{a) Koefisien Korelasi dan Koefisien Determinasi}

Analisa distribusi frekuensi jawaban responden menurut skor dari variabel $\mathrm{X}_{1}$ (Komitmen Pegawai), $\mathrm{X}_{2}$ (Disiplin Kerja) dan Y (kinerja Pegawai) dimaksud sebagaimana telah dilakukan, hanyalah bermanfaat untuk memberikan informasi pendahuluan mengenai pola distribusi jawaban responden menurut skor. Selanjutnya, dilakukan perhitungan korelasi berupa derajat atau kedalaman hubungan fungsional yang menjelaskan hubungan antara perubah, dinyatakan dengan yang dinamakan korelasi yang sering disimbolkan dengan $\mathrm{r}$, nilai $\mathrm{r}$ dapat dihitung menggunakan SPSS versi 21. Hasil korelasi dan koefisien determinasi dapat dilihat pada tabel berikut ini:

Tabel 4

Hasil Koefisien Korelasi dan Koefisien Determinasi

\begin{tabular}{|l|r|r|r|r|}
\hline $\begin{array}{l}M \\
\text { od } \\
\text { l }\end{array}$ & $\boldsymbol{R}$ & $\begin{array}{c}\boldsymbol{R} \\
\text { Square }\end{array}$ & $\begin{array}{c}\text { Adjuste } \\
\text { d R } \\
\text { Square }\end{array}$ & $\begin{array}{c}\text { Std. Error of } \\
\text { the Estimate }\end{array}$ \\
\hline 1 & $.699^{\mathrm{a}}$ &. $\mathbf{4 8 9}$ & .474 & 6.679 \\
\hline
\end{tabular}

a. Predictors: (Constant), disiplin kerja (X2), komitmen pegawai ( X1)

b. Dependent Variable: kinerja pegawai (Y)

Sumber: hasil pengolahan kuesioner

menggunakan SPSS versi 21 (2018) 
Dari hasil korelasi pada tabel 4 di atas diperoleh nilai $r=0,699$ yang artinya terdapat hubungan yang kuat dan positif antara komitmen pegawai, disiplin kerja dengan kinerja pegawai pada Dinas Koperasi, Usaha Kecil Menengah dan Perdagangan kota Pematangsiantar, sesuai dengan kriteria korelasi pada tabel 3.4. Kemudian diperoleh nilai koefisien determinasi $r=0,489$, artinya tinggi rendahnya kinerja pegawai pada Dinas Koperasi, Usaha Kecil Menengah dan Perdagangan kota Pematangsiantar sebesar 48,9\% dapat dijelaskan oleh komitmen pegawai dan disiplin kerja sedangkan sisanya sebesar $51,1 \%$ dipengaruhi oleh faktor lain seperti budaya organisasi, komunikasi, pengembangan karir, kemampuan intelektual, gaya kepemimpinan, pelatihan, kepuasan kerja dan kompetensi pegawai dan variabel lain yang tidak diteliti dalam penelitian ini.

\section{b) Pengujian Hipotesis}

\section{1) Uji Simultan (Uji F)}

Pengujian ini dilakukan secara simultan yaitu dilakukan untuk menentukan diterima atau ditolaknya hipotesis, pengujian hipotesis dilakukan untuk mengetahui apakah variabel komitmen pegawai dan disiplin kerja yang diuji berpengaruh terhadap kinerja pegawai. Jika $F_{\text {hitung }}>F_{\text {tabel }}$ atau signifikansi $\leq 0,05$ maka $\mathrm{H}_{0}$ ditolak. Untuk menguji kebenarannya maka dilakukan pengujian hipotesis dengan menggunakan aplikasi SPSS versi 21.

Tabel 5

Perkiraan Nilai F $_{\text {hitung }}$

\begin{tabular}{|l|r|r|r|r|r|}
\hline Model & $\begin{array}{c}\text { Sum of } \\
\text { Squares }\end{array}$ & Df & $\begin{array}{c}\text { Mea } \\
\boldsymbol{n} \\
\text { Squa } \\
\text { re }\end{array}$ & $\boldsymbol{F}$ & Sig. \\
\hline Regres & 2899.99 & 2 & 1449 & $\mathbf{3 2 . 5 0 0}$ & $\mathbf{. 0 0 0}^{\mathrm{b}}$ \\
sion & 5 & & .997 & & \\
Residu & 3033.86 & 68 & 44.6 & & \\
al & 5 & & 16 & & \\
Total & 5933.85 & 70 & & & \\
\hline
\end{tabular}

a. Dependent Variable: Kinerja Pegawai (Y)

b. Predictors: (Constant),Disiplin Kerja (X2),

Komitmen pegawai (X1)

Sumber: hasil pengolahan kuesioner

menggunakan SPSS versi 21 (2018).

Berdasarkan tabel 5 di atas diperoleh sebesar $32,500>\mathrm{F}_{\text {tabel }}$ dengan $(0,05 ; 2$ vs 68) sebesar 3,13, atau dengan signifikan $0,000<\alpha \quad 0,05$, maka $\mathrm{H}_{0}$ ditolak, artinya komitmen pegawai dan disiplin kerja berpengaruh positif dan signifikan terhadap kinerja pegawai pada Dinas Koperasi, usaha Kecil Menengah dan Perdagangan kota Pematangsiantar.

\section{2) Uji Parsial (Uji t)}

Pengujian ini dilakukan secara parsial yaitu dilakukan untuk menentukan diterimanya atau ditolaknya hipotesis, pengujian hipotesis dilakukan untuk mengetahui apakah variabel komitmen pegawai dan disiplin kerja yang di uji berpengaruh terhadap kinerja pegawai. Jika $t_{\text {hitung }}>\mathrm{t}_{\text {tabel }}$ atau signifikansi $\leq 0,05$ maka $\mathrm{H}_{0}$ ditolak. Untuk menguji kebenarannya maka dilakukan pengujian hipotesis dengan menggunakan program aplikasi SPSS versi 21.

Tabel 6

Perkiraan NIlai $t_{\text {hitung }}$

\begin{tabular}{|l|r|r|}
\hline \multicolumn{1}{|c|}{ Model } & \multicolumn{1}{c|}{$\boldsymbol{t}$} & \multicolumn{1}{c|}{ Sig. } \\
\hline (Constant) & 2.219 & .030 \\
Komitmen & $\mathbf{4 . 0 6 8}$ & $\mathbf{. 0 0 0}$ \\
1 Pegawai (X1) & & \\
$\begin{array}{l}\text { Disiplin Kerja ( } \\
\text { X2) }\end{array}$ & $\mathbf{2 . 0 9 5}$ & $\mathbf{. 0 4 0}$ \\
\hline
\end{tabular}

a. Dependent Variable: Kinerja Pegawai (Y)

Sumber: hasil pengolahan kuesioner

menggunakan SPSS versi 21 (2018).

Berdasarkan tabel 6 di atas, diperoleh nilai $t_{\text {hitung }}$ pada variabel $\mathrm{X}_{1}$ (komitmen pegawai) sebesar 4,068 $>\mathrm{t}_{\text {tabel }}$ dengan $\mathrm{dk}=$ n-k-1 $(71-2-1=68)$ sebesar 1,995 atau taraf signifikan $0,000<\alpha 0,05$, maka $\mathrm{H}_{0}$ ditolak, artinya komitmen pegawai berpengaruh positif dan signifikan terhadap kinerja pegawai pada Dinas Koperasi, usaha Kecil Menengah dan Perdagangan kota Pematangsiantar. Kemudian nilai thitung pada variabel $\mathrm{X}_{2}$ (disiplin kerja) sebesar 2,095 > dari $\mathrm{t}_{\text {tabel }}$ dengan $\mathrm{dk}=\mathrm{n}-\mathrm{k}-1, \quad(71-2-1=68)$ sebesar 1,995 atau taraf signifikan $0,040<\alpha$ 0,05, maka $\mathrm{H}_{0}$ ditolak, artinya disiplin kerja berpengaruh positif dan signifikan terhadap kinerja pegawai pada Dinas Koperasi Usaha Kecil Menengah dan Perdagangan kota Pematangsiantar.

nilai $F_{\text {hitung }}$ dengan $\mathrm{dk}=\mathrm{n}-\mathrm{k}-1 \quad(71-2-1=68)$ 


\section{KESIMPULAN DAN SARAN}

\section{Kesimpulan}

a. Hasil analisis deskriptif kualitatif tentang komitmen pegawai diperoleh nilai ratarata keseluruhan 3,72 dengan kriteria jawaban tinggi. Kemudian nilai rata-rata tertinggi 4,11 dengan kriteria jawaban tinggi untuk dimensi komitmen normatif pada indikator keinginan untuk melanjutkan sisa karir. Sedangkan nilai rata-rata terendah 3,37 dengan kriteria jawaban cukup tinggi untuk dimensi komitmen afektif pada indikator kesediaan mengorbankan kepentingan pribadi demi kemajuan instansi.

b. Hasil analisis deskriptif kualitatif tentang disiplin kerja diperoleh nilai rata-rata keseluruhan 3,52 dengan kriteria jawaban baik. Kemudian nilai rata-rata tertinggi 4,07 dengan kriteria jawaban baik untuk dimensi menjauhi larangan pada indikator memberikan hadiah pada seseorang untuk diangkat dalam jabatan. Sedangkan nilai rata-rata terendah 3,23 dengan kriteria jawaban cukup baik untuk dimensi menjalankan kewajiban dengan indikator menaati ketentuan jam kerja.

c. Hasil analisis deskriptif kualitatif tentang kinerja pegawai diperoleh nilai rata-rata keseluruhan 3,52 dengan kriteria jawaban baik. Kemudian nilai rata-rata tertinggi 3,75 dengan kriteria jawaban baik untuk dimensi sasaran kerja pegawai pada indikator kuantitas pencapaian target, untuk dimensi perilaku pegawai dengan indikator kemampuan dalam bertindak, kerja kelompok bersama rekan kerja, dan kepemimpinan yang bijaksana dalam instansi. Sedangkan nilai rata-rata terendah 3,31 dengan kriteria jawaban cukup baik untuk dimensi perilaku kerja pada indikator tingkat pelayanan.

d. Hasil analisis regresi linier berganda menunjukkan bahwa adanya pengaruh positif antara Komitmen pegawai dan Disiplin Kerja terhadap Kinerja Pegawai pada Dinas Koperasi, Usaha Kecil Menengah dan Perdagangan kota Pematangsiantar. e. Hasil analisis korelasi bahwa terdapat hubungan yang kuat dan positif antara komitmen pegawai, disiplin kerjam dengan kinerja pegawai pada Dinas Koperasi, Usaha Kecil Menengah dan Perdagangan kota Pematangsiantar. Kemudian nilai koefisien determinasi menunjukkan tinggi rendahnya kinerja pegawai pada Dinas Koperasi, Usaha Kecil Menengah dan Perdagangan kota Pematangsiantar dapat dijelaskan oleh komitmen pegawai dan disiplin kerja.

f. Hasil pengujian uji simultan (uji F) menunjukkan bahwa komitmen pegawai dan disiplin kerja berpengaruh positif dan signifikan terhadap kinerja pegawai pada Dinas Koperasi, usaha Kecil Menengah dan Perdagangan kota Pematangsiantar.

g. Hasil pengujian uji parsial (uji t) menunjukkan bahwa komitmen pegawai berpengaruh positif dan signifikan terhadap kinerja pegawai pada Dinas Koperasi, usaha Kecil Menengah dan Perdagangan kota Pematangsiantar. Kemudian hasil pengujian hipotesis untuk X2 menunjukkan bahwa disiplin kerja berpengaruh positif dan signifikan terhadap kinerja pegawai pada Dinas Koperasi Usaha Kecil Menengah dan Perdagangan kota Pematangsiantar.

\section{Saran}

a. Untuk lebih memperbaiki Untuk meningkatkan komitmen pegawai pada Dinas Koperasi, Usaha Kecil Menengah dan Perdagangan kota Pematangsiantar, sebaiknya pimpinan memberikan dukungan dan menjalin komunikasi kepada pegawai agar pegawai bersedia mengorbankan kepentingan pribadi demi kemajuan instansi.

b. Untuk meningkatkan disiplin kerja pada Dinas Koperasi, Usaha Kecil Menengah dan Perdagangan kota Pematangsiantar yang efektif dan efisien, sebaiknya pemimpin lebih mengawasi, menegakkan sanksi disiplin bagi pegawai yang tidak mematuhi ketentuan jam kerja sesuai dengan peraturan yang ada di instansi.

c. Untuk meningkatkan kinerja pegawai pada Dinas Koperasi, Usaha Kecil Menengah dan Perdagangan kota 
Pematangsiantar, pimpinan sebaiknya memberi teguran kepada pegawai yang kurang memanfaatkan waktu dalam menyelesaikan tugas serta pegawai juga sebaiknya memberikan pelayanan yang terbaik untuk masyarakat sesuai dengan peraturan perundang-undangan agar tujuan organisasi dapat tercapai dengan baik.

d. Sehubungan dengan keterbatasanketerbatasan yang ada pada penulis, penelitian ini masih terdapat kelemahankelemahan dan belum dapat mengungkap seluruh variabel yang dapat mempengaruhi kinerja pegawai pada Dinas Koperasi, Usaha Kecil Menengah dan Perdagangan kota Pematangsiantar, sebagai bahan masukan untuk penelitian selanjutnya, perlu memperbanyak variabel penelitian seperti budaya organisasi, komunikasi, pengembangan karir, kemampuan intelektual, gaya kepemimpinan, pelatihan, kepuasan kerja dan kompetensi pegawai dan variabel lain yang tidak diteliti dalam penelitian ini.

\section{E. DAFTAR PUSTAKA}

Bangun, Wilson. 2012. Manajemen Sumber Daya Manusia. Jakarta: Erlangga.

Daft, Richard, L. 2002. Manajemen. Jilid I, Edisi V. Jakarta: Erlangga.

Dharma. Agus. 2004. Manajemen Supervisi. Jakarta: Rajawali Pers.

Griffin, Ricky, W. 2004. Manajemen. Jilid I, Edisi VII. Jakarta: Erlangga.

Handoko, T. Hani. 2003. Manajemen. Edisi II. Yogyakarta: BPFE.

Luthans, Fred. 2006. Perilaku Organisasi. Edisi X. Yogyakarta: ANDI.

Mangkunegara, Anwar Prabu. 2017. Manajemen Sumber Daya Manusia Perusahaan. Bandung: PT. Remaja Rosdakarya.

Mathis, Robert L. dan John H. Jackson. 2006. Human Resources Management. Jakarta: Salemba Empat.
Mondy, Wayne R. 2008. Edisi X. Jilid I. Manajemen Sumber Daya Manusia. Jakarta: Erlangga.

Mulyadi, 2016. Manajemen Sumber Daya Manusia. Cetakan Kedua. Bogor: IN MEDIA.

Panggabean, Mutiara S. 2004. Manajemen Sumber Daya Manusia. Cetakan kedua. Bogor: Ghalia Indonesia.

Peraturan Pemerintah Nomor 53 Tahun 2010. Tentang Disiplin PNS.

Peraturan Pemerintah No 46 Tahun 2011 Tentang Sasaran Kinerja Pegawai.

Robbins, Stephen P dan Mary Coulter. 2010. Manajemen. Edisi kesepuluh. Jilid II. Jakarta: Erlangga.

Robbins Stephen. P dan Timothy A. Judge. 2008. Organizational Behavior. Edisi ke 12. USA: Paerson International Edition, PrenticeHall.

Sastrohadiwiryo, Bedjo. 2002. Manajemen Tenaga Kerja. Jakarta: PT Bumi aksara.

Simbolon, Hotman. 2009. Statistik. Edisi I. Cetakan I. Yogyakarta: Graha ilmu.

Siswanto, Bedjo. 2005. Manajemen Tenaga Kerja Indonesia Pendekatan Administratif dan Operasional. Jakarta: PT Bumi aksara.

Sugiyono, 2016. Metode penelitian Kualitatif kuantitatif Dan R\&D. Bandung: Alfabeta.

Sutrisno, H. Edy. 2011. Manajemen Sumber Daya Manusia. Edisi I. Cetakan Ketiga. Jakarta: Kencana.

Tohardi, Ahmad. 2002. Pemahaman Praktis Manajemen Sumber Daya Manusia. Bandung: $\mathrm{CV}$. Mandar Maju

Wahyu. S. Rio. 2015. Pengaruh Disiplin Kerja Terhadap Kinerja Pegawai Kantor Dinas Pendidikan Pemuda dan Olahraga Kabupaten Bintan. Tanjung Pinang. Universitas 
Maritime Raja Ali Haji

Tanjungpinang. Skripsi.

Wahyudi, Bambang. 2002. Manajemen

Sumber Daya Manusia.

Bandung: Sulita

Wirawan. 2014. Kepemimpinan. Edisi I. Cetakan II. Jakarta: Rajawali Pers.

Zainal, Veithzal Rivai, et. al. 2015. Manajemen Sumber Daya Manusia Untuk Perusahaan dari Teori Ke Praktik. Jakarta: PT. Raja Grafindo Persada. Edisi III. Cetakan Ketujuh. 